\title{
Dr. Keyvan Mazda, The Humble, Humanitarian Physician
}

\author{
Behdad Gharib ${ }^{1,}$, Sara Memarian ${ }^{1}$ and Alireza Mani ${ }^{2}$ \\ ${ }^{1}$ Tehran University of Medical Sciences, Children's Medical Center, Tehran, Iran \\ ${ }^{2}$ Division of Medicine, University College of London, UK \\ "Corresponding author: Pediatrics, Tehran University of Medical Sciences, Tehran, Iran. Email: behdad_gharib@yahoo.co.uk
}

Received 2018 November 03; Revised 2018 November 05; Accepted 2018 November 24.

\section{Dear Editor,}

Keyvan Mazda, the famous, world known pediatric orthopedic surgeon passed away on the 3rd of October 2018 at age 59 in Paris. He was born on 1959 in Abadan (Iran) $(1,2)$ and during his childhood left to France with his family. He studied medicine in France and became a great pediatric orthopedic surgeon, working in Robert Debré Hospital in Paris $(3,4)$.

He worked generously for incapable and disabled children all over the world with Médecins sans Frontiers (Doctors without Borders, the French Medical NonGovernmental Organization) and, La Chaîne de l'Espoir (Chain of Hope, the French Charity Non-Governmental Organization), in Iran and Afghanistan and other countries (3). He invented new methods and devices of pediatric orthopedic surgery and was universally well known for his endeavors and innovations in children's spinal surgery.

During the past 12 years he used to came to Iran fre-

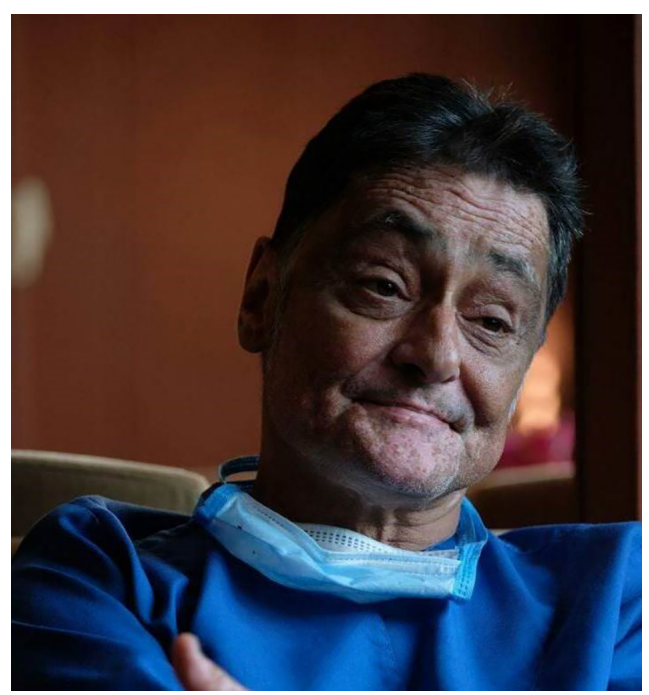

Figure 1. In memoriam Professor Keyvan Mazda the humble, humanitarian physician quently and operated many underprivileged patients with scoliosis in Children's Medical Center, Sina, Shariati. and Noorafshar hospitals. In Tehran his clinic was the host and receptive of ill children from all over the country. Many Balouch, Kurds, Turks, Arabs, and other ethnicities of our colorful and diverse Iran used to come to his clinic.

Zanjireyeh-Omid Charity Institute (the Iranian Charity Organization) supported his team and his patients during his visits to Iranian hospitals (5). Dr. Mazda also generously received Iranian physicians in his clinic in France in order to improve their clinical and surgical skills $(5,6)$.

He was Iranian-French, with Zoroastrian roots (2) and maybe that is why he had the feeling to follow the Zoroastrian ancient attitude of "good thoughts, good words and good deeds" of his origin. However these humans are far from being defined by religion and nationality but Iranians and Iranian physicians are proud to be his compatriot. In the era of supremacy and domination of material things he is the example we were searching for, however he mentioned once "I am not an example, I am just trying to be myself".

He had more than one hundred publications in medical journals and developed the Universal Clamp method for spinal scoliosis surgery and invented new methods and instruments in spinal surgery $(7,8)$. But his great achievement has been the good deeds, charity working and the benevolence in the era of violence of our time.

We, doctors of Children's Medical Center Hospital, had the honor and privilege of working with him in our hospital and we express our sincere condolences to his family, Iranians, the Zoroastrian community and all physicians and humans who wish and try to follow his path.

\section{Footnotes}

Conflict of Interests: It is not declared by the authors. Funding/Support: It is not declared by the authors. 


\section{References}

1. Tehran Times, 7th of October 2018. 2018. Available from: https: //www.tehrantimes.com/archive?pi=1\&ty=14\&ms=2\&ps $=30 \&$ $\mathrm{dy}=7 \& \mathrm{mn}=10 \& \mathrm{yr}=2018$.

2. The news website of Zoroastrians of Iran. 2019. Available from: www. Berasad.com.

3. Wikipedia. 2019. Available from: https://fa.wikipedia.org/wiki
4. The official website of the public relation office of Tehran University of Medical Sciences. 2019. Available from: https://pr.tums.ac.ir.

5. The official website of Zanjireh Omid Charity Institute. 2019. Available from: www.zanjirehomid.com.

6. The official website of the embassy of France in Iran. 2019. Available from: https://ir.ambafrance.org.

7. Patents by inventor Keyvan Mazda.2019. Available from: https://patents justia.com/inventor/keyvan-mazda.

8. Scopus. 2019. Available from: www.scopus.com. 